\title{
EFFECTS OF TREE MORTALITY ON POWER LINE SECURITY
}

\section{by Siegfried Guggenmoos}

\begin{abstract}
Others have reported that instances where trees grow into lines rarely result in power outages. The vast majority of tree-related outages stem from tree failure, particularly if outages during severe weather events are included. Generally, tree-conductor conflicts resulting from tree failure are classified as unpreventable because the trees are located outside the right-of-way. In the emerging competitive environment, utilities will require a means of decreasing so-called unpreventable outages. The primary locations for unpreventable outages are areas where lines run adjacent to or through natural forest tree stands. Tree mortality exposes a power line to a high risk of tree incidents over time. The risk to the line is directly related to the number of trees within striking distance of the line. Conventional clear widths leave a substantial residual tree risk. Hazard tree removal programs do not provide enduring reliability gains. A new mathematical model, the optimal clear width calculator, is used to assess the tree risk over variable clear widths and line heights. The risk ratings in the output line strike probability charts permit quantitative comparisons of construction and maintenance options. The line strike probability chart indicates that there is a point of diminishing return in line security for dollars invested in additional clear width.
\end{abstract}

Key Words. Utility arboriculture; hazard tree; tree-related outages; tree-conductor contacts; electric system reliability; tree mortality; line strike risk; tree risk quantification.

\section{BACKGROUND}

It is estimated that North American utilities spend $\$ 2$ billion (Rees et al. 1994; EPRI 1995; Goodfellow 2000) to $\$ 10$ billion (Transmission \& Distribution World 2002) annually on vegetation management to prevent service disruptions and safety hazards associated with trees contacting conductors. Throughout their 100-year history, utilities have been challenged by tree-conductor conflicts that continue to plague them today.

Trees are a major cause of power outages, particularly on distribution systems. On distribution systems, treerelated outages comprising 20\% to $50 \%$ of all unplanned outages are common (Rees et al. 1994; Simpson and Van Bossuyt 1996; Johnstone 2001). Tree-related outages exceeding $50 \%$ of the total tend to draw attention to the need for remedial action (St. Petersburg Times 1999; Megawatt Daily 1999; Poole and Clements 2000). While these percentages indicate that trees are a major threat to reliability, the convention of excluding outage statistics arising from severe storm events (Louisiana Public Service Commission 1998; California Public Utilities Commission 2000; Carris 2000; Michigan Public Service Commission 2000; Finch and Allen 2001; Oregon Public Utility Commission 2001) means the extent of the problem is vastly understated.

Utilities are in the business of generating electricity and delivering electricity and/or electrical service. They invest in and install equipment to condition and transport electricity to the point of use. This equipment, essential to providing the service that constitutes the business, is an asset. That which holds the potential of disrupting the service and thereby the revenue stream constitutes a financial liability. From a utility business perspective, all trees capable of growing into or on failure striking a power line are not only a legal liability due to human safety and property concerns but also a financial liability.

Considering the long history of attention and resources focused on reducing or eliminating tree-conductor conflicts, the extent of the ongoing level of tree-related outages suggests something is missing. Utility foresters balance a plethora of competing interests. Challenged to satisfy the need for safe, reliable, and economic electric service; easement conditions; property rights; regulations; environmental concerns; tree ordinances; public perceptions; and aesthetics, one understands how it might be difficult "to see the forest for the trees."

Tree-related outage statistics provide information about the extent of tree exposure and efficacy of the line-clearance program. However, these statistics are after the fact. The intent of this article is to provide a means of understanding and quantifying tree risk in advance of failure events. This search for a conceptual framework for sustainable treerelated outage reductions takes a dispassionate view, focusing on trees, how forest stands develop and die, characteristics of the electrical system and utility business, and how they interact to impact reliability.

In developing the conceptual framework, this article will examine from a North American perspective: 
- the increasing pressure on utilities to reduce service disruptions

- the source of tree-related outages

- natural tree mortality and predictive modeling of tree mortality

- the implications of tree mortality for conventional hazard tree identification and removal program cycles and intensity

- an approach to quantifying the risk of tree line strikes

- using the cost of changes in tree risk to decide among maintenance options

- the relationship between target clearance and tree risk

The primary audience for this article is utility foresters. Secondary audiences include utility asset managers, utility arboriculture consultants, utility regulators, forest managers, and other stakeholders. Terminology used draws both from utility and forestry domains. Standards and units used in examples have been selected based on wide commonality in the North American utility industry.

It will be demonstrated that the majority of the risk associated with the tree liability arises from trees outside the maintained right-of-way (ROW). Tree failure events that disrupt electric service are weather related (Simpson and Van Bossuyt 1996; Desbiens 2001; Finch and Allen 2001; Rogers 2001; Tomich 2001; Keener, no date). Because severe weather may cause healthy, defect-free trees to fail (Simpson and Van Bossuyt 1996; Desbiens 2001; Finch and Allen 2001; Tomich 2001; Keener, no date), all trees capable of interfering with power lines are included in the risk assessment. In viewing all trees capable of interfering with power lines as a liability, the assessment of tree risk assumes a worst-case scenario. Hence, the quantification of the tree risk as presented should be seen as the base case that will be modified by other risk factors such as species-specific failure characteristics and the frequency of severe storms, drought, and pest infestations.

Nonetheless, tree risk assessment can be used on a comparative basis. As such, the quantitative tree risk assessment constitutes a tool that will provide

- a means for progressive reliability improvements

- another method of assessing the role of trees on circuits experiencing poor reliability

- a means of setting specific, acceptable, residual tree risk levels

- a basis for prioritizing investment to maximize reliability gains and minimize losses

- a means of rationalizing capital investment in equipment or methodologies that prevent tree-caused outages

- a means of illustrating to regulators the need for and prudence of line-clearance maintenance decisions and funding
The use of a broad, inclusive definition for the tree liability should not be construed to suggest that utilities reduce the tree risk to zero by removing all trees capable of interfering with power lines. Not only would such a decision be met with public and regulator resistance but also, as will be demonstrated, it would not be financially prudent.

\section{CONTEXT FOR TREE-CONDUCTOR CONTACTS AND SERVICE DISRUPTIONS}

In little more than a decade, a firestorm in Washington (Partners in Protection 1999), the burning of a historical California town (EnergyOnline 1997a, 1997b; Olsen 2001) and two major western U.S. grid crashes (EnergyOnline 1996a, 1996b, 1996c) have been attributed to treeconductor contact. In western North America, where summer forest conditions tend to be dry, tree-conductor contacts are a frequent cause of forest fires (EnergyOnline 1997c, 1998a; Partners in Protection 1999).

Utilities in eastern North America face ice storms (EnergyOnline 1998a; Desbiens 2001). In the south and southeastern United States, windstorms are relatively frequent events (Electric Perspectives 2001; Tomich 2001; Keener, no date). While the stress these events place on the electrical system results in direct equipment failures, often the majority of outages associated with these events are indirect. They are the result of tree failures (Megawatt Daily 1999; PRNewswire 1999; Tomich 2001).

The risk of major system outages caused by severe weather events is increasing. Climatologists studying global warming predict greater variability in weather in the future. They forecast the number and severity of major weather events will increase (Watson et al. 1998). The trend may already be established. During the past 21 years, 48 extreme weather events, each with estimated damages exceeding US $\$ 1$ billion, hit the United States. Of these, 41 have occurred in the past 12 years (Hadden 2001).

The transmission component of the electrical system is experiencing unprecedented load. Due to the business uncertainty associated with evolving regulation toward competitive markets and public resistance to siting new transmission lines, expansion of the transmission system has not kept pace with growing electricity demand (Owens 2001).

A new trend emerging from public utility commissions is to specify reliability targets that must be met (Kjellstrand 1998; Rights-of-Way Online 1999; Grayson 2001). The number of states in the United States that have set reliability standards increased from three in 1996 to 27 in 2001 (Bush 2002). A variant is performance-based ratemaking, under which utilities will be financially rewarded for exceeding reliability goals and, in some cases, punished for failures to meet them (Grayson 2001). As of 2001, 11 states in the United States have penalties and awards for performance (Bush 2002). The effects of major storms on the reliability 
statistics are excluded from the base targets. However, public utility commissions are increasingly questioning whether a utility's past maintenance practices have not compounded the extent of storm damage (EnergyOnline 1998b; Tomich 2001).

With the shift to and expansion of the digital economy, reliability of the electric system takes on previously unimagined significance. The annual U.S. economic loss due to power outages is estimated to range from a conservative US\$50 billion (EPRI 1995) to US\$100 billion (Lewis 2001).

In a recent RKS Research \& Consulting survey (Business Wires Features 2001), 75\% of the respondents said it "doesn't matter which company supplies ... electricity, as long as delivery is reliable."

Evolving customer and regulator expectations suggest that an approach of classifying tree-related outages as nonpreventable will no longer be acceptable. The need for reliable service has increased dramatically. Due to costs, the digital economy is completely intolerant of outages (Lewis 2001). One might expect the most flexibility and tolerance with light-load residential and small commercial customers. However, it is unknown how long these customers, dependent on electric service for security, comfort, productivity, convenience, and recreation, will continue to be forgiving for outages stemming from major storm events. Failure to address the reliability issue will drive customers to adopt the emerging distributed generation technologies to free themselves of the grid.

\section{SOURCE OF TREE-RELATED OUTAGES}

To reduce tree-related outages, it is necessary to examine the origin of tree-related outages (Rees et al. 1994; Guggenmoos 1996; Simpson and Van Bossuyt 1996; Goodfellow 2000). Tree-related outages can be classified into two groups based on fault type: those attributable to tree growth and those attributable to tree failure.

When a pruning program begins to fall behind, tree branches grow into conductors. Initially, as branches begin to make contact with energized distribution conductors, the shoots tend to be "burned off" through momentary contact (Figure $1^{*}$ ). At this early stage of tree-conductor contact, rarely would we expect a fault to occur. Rees, of Baltimore Gas \& Electric, attributed only 2\% of all tree-related outages to trees growing up into a line (Rees et al. 1994). Guggenmoos showed tree growth to account for $2 \%$ to $10 \%$ of treerelated outages on TransAlta Utilities' distribution system (Guggenmoos 1996). Finch, reporting on Niagara Mohawk's tree-caused outages, indicated that tree growth accounts for 14\% of outages (Finch and Allen 2001), while Rogers explained that part of the reasoning behind Puget Sound Energy's Tree Watch program is that only $13.5 \%$ of treerelated outages are attributable to tree growth (Rogers 2001). From these geographically and ecologically diverse utility systems, a common thread emerges: Tree growth into power lines accounts for less than $15 \%$ of all tree-related outages. A marked increase in outages due to growth is not likely to occur until the pruning program is so far behind cycle that tree branches are of a more substantial diameter and in simultaneous contact with two phases (Rees et al. 1994; Goodfellow 2000; Finch and Allen 2001).

Notwithstanding, this finding should not be interpreted to mean that trees growing into distribution lines are not a risk. Safety and fire hazard risks increase in relation to the decreasing clear distance among trees and bare conductors and number of incidents of tree-conductor contact. These risks represent a legal liability not only to utilities but also directly to utility executives and directors (Guggenmoos 1996; EnergyOnline Daily News 1997a, 1997b).

Tree-conductor contacts arising from tree failure will in most cases result in a fault by

- breaking the conductor or bringing it to the ground

- bringing phases into contact with each other

- making a substantive bridge between phases-allowing a carbon path to develop and leading to a short (Rees et al. 1994; Goodfellow 2000; Finch and Allen 2001)

Where maintenance practice does not remove overhangs, some electrical faults will arise from trees within the right-of-way (Finch and Allen 2001); however, the majority of tree-caused outages are the result of failure of trees outside the right-of-way. The number of trees capable of striking the line from outside the right-of-way vastly outnumbers the trees on it. This is particularly true for distribution lines, which comprise roughly $90 \%$ of the electric grid. North American distribution line heights are generally 6.1 to $9.1 \mathrm{~m}$ (20 to $30 \mathrm{ft}$ ). Maintained right-of-way width for distribution lines is commonly 6.1 to $9.1 \mathrm{~m}$, with a clear width of 3 to $4.5 \mathrm{~m}$ (10 to $15 \mathrm{ft}$ ) (Figure 2). Where such distribution lines run through $24.2 \mathrm{~m}(80 \mathrm{ft})$ tall tree stands, the maintained right-of-way area represents only $12 \%$ to $19 \%$ of the total area from which tree-conductor conflicts can arise. Along transmission lines, where voltages are higher, a greater percentage of the area from which tree conflicts could arise needs to be and typically is maintained as right-of-way. The maintained portion may comprise 100\% of this area but more commonly comprises $30 \%$ to $70 \%$. The tree risks in the transmission line wire zone are readily recognized (EnergyOnline 1996a, 1996b, 1996c; Goodfellow 2000) and providing adequate funding are generally addressed. Hence, it is the off-ROW trees that will constitute the larger source of outages, particularly under severe weather conditions.

On TransAlta's distribution system, where all overhangs were removed, $90 \%$ to $98 \%$ of tree-caused outages were due to tree failure (Guggenmoos 1996). It is estimated that $95 \%$ or more of these failures were trees beyond the 
maintained right-of-way. Finch reports 86\% of tree-caused outages result from trees outside the right-of-way (Finch and Allen 2001). Similarly, on the west coast, Rogers reports that $66 \%$ of PSE's outages are caused by trees greater than $4.5 \mathrm{~m}$ (15 ft) from the nearest conductor (Rogers 2001). If tree-related outages are to be substantially reduced, offROW trees will need to be addressed.

Addressing the safety and reliability risks of off-ROW trees represents an enormous challenge to utilities. Power lines run through or adjacent to an enormous number of trees. Thirtythree percent of the United States and 56\% of Canada are forested (Smith and Sheffield 2000; Forestinformation.com, no date). Most of these trees are natural. Only $7 \%$ are planted (Forest Service 2001). The extent of the liability will vary geographically. Maine is $90 \%$ forest covered, while Iowa has only $5.7 \%$ forest cover (Forest Service 2000). In U.S. urban areas, tree cover is $27 \%$ (U.S. Forest Service 2001).

On distribution systems where a large portion of the tree-related outages are attributable to tree growth, the pruning maintenance cycle is too long and divorced from the tree inventory and tree growth rates. Conceptually, this problem is easy to resolve since the underlying cause of this condition is inadequate funding. Where tree failure is the major source of tree-related outages, resolution of the problem is more complex and certainly not as apparent.

\section{TREE MORTALITY AND IMPLICATIONS FOR UTILITY MAINTENANCE PRACTICE}

Trees may be power line hazards because of lean; a poor anchoring medium; poorly formed, narrow angle crotches; codominant leaders; and other structural defects. Such trees are removed in a hazard tree program. But what of trees that have no physical defects yet succumb to competition for light, water, and nutrients? An examination of natural tree mortality is warranted.

Data for lodgepole pine (Pinus contorta) in Alberta, Canada (Johnstone 1976), reveal that between age 20 and 100 years, about 4,000 trees per hectare die (Table 1). Lodgepole pine is a fire-origin species. Stands are even-age and quite uniform. In the first 30 years, the trees are not of a height where they are likely to cause service interruptions. In Table 1, the column titled relevant mortality provides a cumulative total of dead trees per hectare in excess of $11.8 \mathrm{~m}$ (39 ft) in height. The mortality is considered relevant because these trees, in the vicinity of a distribution lines, hold the potential to cross phases, start fires, and disrupt service. Typical distribution line height is 6 to $9 \mathrm{~m}$ (20 to $30 \mathrm{ft}$ ). Tree mortality that poses a threat to distribution lines is almost 3,500 trees per hectare over 70 years. Putting that into a utility context, a hectare is about $1 \mathrm{mi}$ by $20 \mathrm{ft}$ wide. For a power line running alongside such a lodgepole pine forest, about 3,500 trees die over a 70-year period within a $20-\mathrm{ft}$ strip just outside the maintained right-of-way. Taking, for
Table 1. Lowest density $(1,236 / \mathrm{ha}$ at 70 years $)$ yield table for lodgepole pine (Pinus contorta) on an "average site" in Alberta (adapted from Johnstone 1976). Relevant mortality refers to trees greater than $11.8 \mathrm{~m}$ (39 ft) in height.

\begin{tabular}{llcccc}
\hline Age & Trees/ac & Trees/ha & $\begin{array}{c}\text { Dominant } \\
\text { height }(\mathrm{ft})\end{array}$ & $\begin{array}{c}\text { Dominant } \\
\text { height }(\mathrm{m})\end{array}$ & $\begin{array}{c}\text { Relevant } \\
\text { mortality }\end{array}$ \\
\hline 20 & 1,793 & 4,431 & 26 & 8 & 0 \\
25 & 1,780 & 4,398 & 29 & 9 & 0 \\
30 & 1,603 & 3,961 & 34 & 10 & 0 \\
35 & 1,403 & 3,467 & 39 & 12 & 494 \\
40 & 1,215 & 3,002 & 44 & 13 & 959 \\
45 & 1,047 & 2,587 & 49 & 15 & 1,374 \\
50 & 902 & 2,229 & 53 & 16 & 1,732 \\
55 & 777 & 1,920 & 57 & 17 & 2,041 \\
60 & 670 & 1,656 & 61 & 19 & 2,305 \\
65 & 578 & 1,428 & 64 & 20 & 2,533 \\
70 & 500 & 1,236 & 67 & 20 & 2,726 \\
75 & 434 & 1,072 & 69 & 21 & 2,889 \\
80 & 378 & 934 & 72 & 22 & 3,027 \\
85 & 331 & 818 & 74 & 23 & 3,143 \\
90 & 292 & 722 & 76 & 23 & 3,240 \\
95 & 261 & 645 & 78 & 24 & 3,316 \\
100 & 235 & 581 & 79 & 24 & 3,380 \\
\hline
\end{tabular}

the sake of simplicity, a straight line average, that amounts to an annual average of 50 trees per hectare $(20 \mathrm{ft} \times 1 \mathrm{mi})$ that become susceptible to failure.

Of course, only a percentage of these 50 trees per hectare capable of striking the line on failure will do so. However, we can reasonably expect that the number of treecaused outages is directly proportional to the degree of exposure, measured in standing hazard trees.

Other fire-origin species-jack pine (Pinus banksiana) and trembling aspen (Populus tremuloides) — of the Canadian boreal forest (Figure 3) follow a similar pattern of mortality. Over 50 years, the stand density declines $70 \%$. For young South Carolina forests (Figure 4) predominated by pines (Pinus spp.), oaks (Quercus spp.), maples (Acer spp.), yellow poplar (Liriodendron tulipifera), and black gum (Nyssa sylvatica), which would typically evolve into uneven-age stands, stand density is found to decline 60\% over 50 years (Crookston 1997). Tree mortality for the South Carolina forest stands represented in Figure 4 amounts to 36 trees ha ${ }^{-1} \mathrm{yr}^{-1}\left(\mathrm{mi}^{-1} \mathrm{yr}^{-1}\right.$ over a $20 \mathrm{ft}$ width). Mortality skewed to small-diameter-class trees, as one would expect for uneven-age stands, is not a factor because there is no accretion built into the stand model used (Lilly 2000). Still, not all of the trees have the height to interfere with power lines. Most do, however, since they achieve $12.1 \mathrm{~m}$ (40 ft) in height in 20 years. Eliminating the short trees from the South Carolina data to focus on annual mortality relevant to utilities reduces the rate to 23 to 25 trees $\mathrm{ha}^{-1} \mathrm{yr}^{-1}$.

Some of the lowest tree mortality rates appear in the U.S. Pacific Northwest. Using the Suppose simulator (Crookston 
1997), forests stands comprising Douglas-fir (Pseudotsuga menzeisii), ponderosa pine (Pinus ponderosa), western larch (Larix occidentalis), grand fir (Abies grandis), and lodgepole pine show a $40 \%$ stand reduction over 90 years (Figure 5 ). Considering accretion and higher mortality of small diameter trees (Johnson 1990), the average annual mortality relevant to utilities is 18 trees per hectare.

All of the preceding forest stands examined have been young stands. Old stands, however, follow the same pattern (Figure 6), though the average annual mortality in trees is lower because the number of trees in the stand is lower. For this 500-year-old stand of ponderosa pine and Douglas-fir (Crookston 1997), the predicted average annual mortality is 7 trees per hectare. Given that only $6 \%$ of U.S. timber is more than 175 years old and that $55 \%$ of the U.S. forests are less than 50 years old (U.S. Forest Service 2001), most electric line exposure will be to forest stands having a relatively high tree density.

The diverse forest stand examples provided show that while the total number of trees and the rate of mortality varies by species and location, the trend of a declining viable tree population over time, is common. It is true for even-age and uneven-age stands. Inter- and intra-species competition for light, water, and nutrients drives the decline in tree population. Periods of stress caused by drought or pests accelerate the rate of mortality.

To understand the implications of the declining tree density on power line security, the data for lodgepole pine in Alberta (Johnstone 1976) are graphed to highlight the number of dead and decadent trees (Figure 7). The mortality data have been altered to exclude trees that die before achieving a height that is likely to pose a serious risk to a distribution line (relevant mortality column in Table 1). Death in trees is a process that may occur over months to years, and dead trees may stand for extended periods of time. Figure 7 shows how the risk to power lines accumulates. It provides a stimulus for further inquiry and examination of the rate of hazard tree development in the context of utility maintenance operations.

From the data used to generate Figures 3 through 6 , illustrating the viable stand populations, tree mortality rates ranging from 7 to 50 trees per hectare per year were derived. It has been stated that 1 ha equals $1 \mathrm{mi}$ by $20 \mathrm{ft}$. When the height of trees is considered, evaluating the hazard over only the first $20 \mathrm{ft}$ of the adjacent forest will generally be inadequate. Summing mortality for 3 ha, or over $60 \mathrm{ft}$ per mile, would appear a more reasonable approach. For example, this assumption would fit a distribution line with a $3 \mathrm{~m}(10 \mathrm{ft})$ clear width adjacent to 21.2 to $24.2 \mathrm{~m}$ (70 to $80 \mathrm{ft}$ ) trees or a transmission line with a $9.1 \mathrm{~m}$ ( $30 \mathrm{ft}$ ) clear width adjacent to 27.3 to $30.3 \mathrm{~m}$ (90 to $100 \mathrm{ft}$ ) trees. Based on the need to consider the risk arising over $60 \mathrm{ft}$ rather than $20 \mathrm{ft}$, the number of dead trees posing a risk to power lines then increases by a factor of 3, from 21 to 150 trees $\mathrm{mi}^{-1} \mathrm{yr}^{-1}$ per ROW side.

The natural phenomenon of decreasing viable tree density over time for forests represents an enormous risk to line security. However, this risk is frequently ignored and not quantified because the trees constituting this risk are usually outside the right-of-way. While inventories may include offROW hazard trees, it is a static snapshot of conditions at a particular time. There has not been a predictive model for the development of hazard trees. Rather, utilities that recognize off-ROW hazard trees as substantial risk to line security tend to have a program of cyclical field inspections to monitor and identify hazard trees. Assuming a 5-year cycle for hazard tree identification and removal, the lowest tree mortality rate found (U.S. Pacific Northwest interior) necessitates the removal of 105 ( 21 trees $\left.\mathrm{mi}^{-1} \mathrm{yr}^{--} \times 5 \mathrm{yrs}\right)$ trees per mile per ROW side per maintenance cycle. For lodgepole pine and other fire-origin species, the required removals expand to $750\left(150\right.$ trees $\left.\mathrm{mi}^{-1} \mathrm{yr}^{-1} \times 5 \mathrm{yrs}\right)$ trees per mile per ROW side. This requirement is two orders of magnitude above what would be considered by the utility industry a typical hazard tree program. Considering the rate of tree mortality, a hazard tree program that successfully removes the emergent risk of line strikes would necessarily be a major operation. It would be noticed in the utility arboriculture industry much as Puget Sound Energy's Tree Watch program has been (Rogers 2001).

Utility arborists and researchers have focused considerable effort on better hazard tree identification. While this effort is useful, the sheer volume of trees dying under normal conditions suggests that unless the maintenance cycle is drastically reduced and the number of hazard trees identified and removed per cycle is greatly increased, the risk of treeline contacts will not be meaningfully reduced. Complicating the matter is that better than half the trees that fail show no noticeable defects (Simpson and Van Bossuyt 1996; Finch and Allen 2001). Shifting from typical hazard tree programs to ones that fully address natural tree mortality would escalate the costs at least 20 times, which casts doubts on the feasibility of improving line security through a hazard tree program. The examination of natural tree mortality leads to the conclusions that improving line security through a hazard tree program will be extremely challenging and, where gains are made, the results will not be enduring.

\section{QUANTIFYING TREE MORTALITY}

Tree mortality rates depend on local tree species and conditions. A cursory review of various stand data suggests annual mortality rates ranging from $0.5 \%$ to $3 \%$ are quite common (Johnstone 1976; Plonski 1981; Campbell and Liegel 1996; Crookston 1997; Harmon 1999; Curtis et al 2000; U.S. Forest Service 2001). The lowest tree mortality rates uncovered in this review occurred in the interior 
Pacific Northwest. Annual mortality rates of $0.3 \%$ to $0.5 \%$ were observed in ponderosa pine forests (Harmon 1999). Mortality in coastal forests of Sitka spruce and western hemlock is highly variable, ranging from $0.8 \%$ to $3.0 \%$ per year (Harmon 1999).

Examination of local forest stand data representative of the area will reveal the annual mortality. While this determination is necessary, annual percentage of mortality is not directly useful. Application requires the current tree density be known so as to transform percentage to trees per unit (i.e., mile) of line. It is expected that most North American utilities will find tree mortality will annually add 50 to 150 trees $\mathrm{mi}^{-1} \mathrm{yr}^{-1}$ per $60 \mathrm{ft}$ of treed ROW side to the workload. Given such a spread, utilities will want to quantify the tree risk specific to their area. A model that can predict tree mortality based on current or found tree densities would be useful. A comparison of the number of trees added to the workload through mortality versus the number removed by the hazard tree program will reveal the impact of tree mortality on future workload. This information may prove useful in attracting more funding for vegetation management.

In calculating annual tree losses, as was done for lodgepole pine, a straight-line average was used for the sake of convenience. This method may appear fitting for the Pacific Northwest interior (Figure 5) and even the South Carolina mixed-wood forests (Figure 4). Mortality rates in fire-origin species (Figure 3) clearly do not follow a linear pattern.

The percentage of annual mortality in Figures 3, 4, and 5 is modeled. The same geometric progression was used in each case, altering the mortality rate for the best fit to the observed data. The algorithm used is

$$
P_{t n}=P_{t 0} \times 1 /(1+M R)^{t n-t 0}
$$

where

$P$ is tree population (trees/ha)

$M R$ is mortality rate

to is the stand age in years at the start of the period $t n$ is stand age in years at the end of the period considered

Using this equation to predict the residual tree population a good fit was achieved for several different forest types (Figures 3,4, and 5). It can be seen that a calculated 3\% rate of annual mortality produces a curve that fits fire-origin species quite well, while an annual mortality rate of $1.7 \%$ fits the South Carolina mixed-wood example where the tree density changes appear linear. Thus, at low mortality rates, this equation yields a declining population approaching a straight line, whereas higher mortality rates result in a curved population decline. While this algorithm provides a tight fit between forecast and actual stand mortality for the provided examples, the number of stands considered is small. This algorithm is not suitable as a predictive tool for all forest stands. Its output will need to be compared to local forest stand data to pre-test its utility. Should it be found lacking, error can be restricted by limiting forecasts of mortality to 20 years or less. For longer-term predictions, local forest researchers will be able to provide suitable algorithms (Crookston 1997).

Discussion has focused on tree mortality in unmanaged stands. Since this tree mortality is based on competition for light, water, and nutrients, forest management practices such as commercial thinning that effectively decrease competition between trees will decrease both the mortality rate and the number of dead trees. Lines running through managed stands are not devoid of line strike risks, but the rate of tree mortality may be half that of the unmanaged stands (Curtis et al. 2000).

\section{RISK REDUCTION THROUGH HAZARD TREE REMOVAL}

Most utilities strive to handle the risk of off-ROW treecaused outages through a hazard tree identification and removal program. To determine if this constitutes a reasonable and effective approach requires an examination of a typical hazard tree program and the rate of development of hazard trees or tree mortality.

To assess the potential of a hazard tree program to mitigate the risk of tree-line strikes, an example for a $69 \mathrm{kV}$ line will be used. This voltage, in the lower end of transmission service, is chosen because the tree-conductor clearances maintained will fall between those for higher voltage transmission lines and the lower voltage distribution lines.

Assume the following conditions:

- A $69 \mathrm{kV}$ line is set on an $18.3 \mathrm{~m}$ (60 ft) right of way.

- The line is built on $3 \mathrm{~m}(10 \mathrm{ft})$ cross arms, and the average conductor height is $12.2 \mathrm{~m}(40 \mathrm{ft})$.

- Sixty percent of the line runs adjacent to a forest edge.

- Dominant tree height is $25.9 \mathrm{~m}$ ( $85 \mathrm{ft}$ ), and tree density is 620 trees/ha (250 trees/ac).

- A hazard tree program is in place. It is on a 5-year cycle and removes an average of 18.75 trees per kilometer (30 trees per mile).

(An informal survey (2001-2002) of seven utilities found that hazard trees are removed as a part of the normal maintenance cycle. The maintenance cycle ranged from 3 to 7 years except in Hawaii where the cycle is much shorter. Most hazard tree programs removed about 5 trees per mile, with the most intense averaging 10 to 15 trees per mile. A hazard tree program removing 30 trees per mile was viewed as very aggressive and a major undertaking by all the utilities surveyed.) 
From this, we can calculate:

- Clear width $=7.6 \mathrm{~m}=25 \mathrm{ft}[(60 \mathrm{ft}$ ROW $-10 \mathrm{ft}$ cross arm)/2]. (Clear width is the distance measured on the ground from the trunks at the tree line to the nearest conductor. See Figure 2.)

- Trees up to $22.7 \mathrm{~m}$ (75 ft) from the nearest conductor could strike the line (as determined by triangulation).

- Residual trees occur over $22.7 \mathrm{~m}-7.6 \mathrm{~m}=15.1 \mathrm{~m}$ $(75 \mathrm{ft}-25 \mathrm{ft}=50 \mathrm{ft})$ of ROW side of exposure.

- The residual tree population is 947 trees $/ \mathrm{km}=1,515$ trees $/$ $\mathrm{mi}[(50 \mathrm{ft} \times 5,280 \mathrm{ft} / \mathrm{mi}) / 43,560 \mathrm{ft} / \mathrm{ac} \times 250$ trees/ac] .

- The residual tree population is decreased by $2 \%$ through the hazard tree program (30 trees $\mathrm{mi}^{-1} / 1,515$ trees $\mathrm{mi}^{-1}$ ).

A good hazard tree identification and removal program may substantially improve line reliability. However, the risk addressed by the hazard tree program is only that of trees perceived to be susceptible to failure. The risks associated with the impact of lightning, severe wind, and ice loading on healthy, structurally sound trees are not addressed by a hazard tree program because sound, healthy trees are not removed. This risk is not insignificant. Many utility foresters will attest to the fact that as many as half the trees that fail show no noticeable defects. An Eastern Utilities study found that only $44 \%$ of the trees or limbs that failed had an indicator of structural weakness (Simpson and Van Bossuyt 1996). Niagara Mohawk found of the trees that failed, $36 \%$ were dead and 64\% were live (Finch and Allen 2001).

A $2 \%$ reduction in the residual tree population examined in the context of typical tree mortality rates of $0.5 \%$ to $3 \%$ per year (Johnstone 1976; Plonski 1981; Campbell and Liegel 1996; Crookston 1997; Harmon 1999; Curtis et al 2000; U.S. Forest Service 2001) reveals that the benefit of even a very aggressive hazard tree program as used in this example will only be significant for a relatively short time. Most of the reliability gain will erode prior to the next maintenance cycle. Since we cannot predict which of the residual trees will next become decadent, the enduring outcome of the example hazard tree program is no more than a $2 \%$ reduction in tree-line strike risk.

Given the same tree characteristics, the residual tree population is lower for higher-voltage transmission lines due to a greater maintained tree-conductor clearance and line height. Thus, removing 18.75 trees per kilometer (30 trees per mile) would yield a greater risk reduction. Conversely, for distribution lines, due to smaller maintained tree-conductor clearances and lower line heights, the residual tree population is higher; hence, removal of 18.75 trees per kilometer (30 trees per mile) yields a smaller percentage change.

This example serves to illustrate that the extent of the risk arising from off-ROW trees is not meaningfully addressed, in an enduring fashion, through a typical hazard tree identification and removal program.

\section{QUANTIFYING THE RISK OF TREE-LINE STRIKES}

For power lines running adjacent to or through forests or natural tree stands, the risk of tree-conductor contact is directly related to the number of trees within striking distance of the line. This risk far outweighs the risk arising from trees considered part of the normal maintenance regimen, which places the emphasis on trees within the ROW requiring pruning. The rate of tree mortality has been shown to constitute a far greater risk to reliability than has been previously recognized. How might the tree risk be mitigated?

The tree risk can be quantitatively mitigated by decreasing the number of trees capable of striking the line either by increasing the clear width or the line height.

To determine the effects of clear width (clear width and clear distance are used interchangeably) on line security, tree canopy height, tree density, and the line height can be used in a mathematical derivation (optimal clear width calculator, Guggenmoos 2000) of risk exposure. The graphic output, the line strike probability chart (Figure 8), shows how the risk of line strike changes with the clear width. The derivation of risk shown in the line strike probability chart assumes all possible directions of tree fall have an equal probability. All trees capable of striking the line are considered equal regardless of condition. It reflects differences in mortality based on species only indirectly through tree density (see Figure 3 ). The ability to withstand wind and ice or snow loading, species-specific patterns of decay and failure, and the probability of weather events of specified severity are not incorporated when producing the line strike probability chart. The risk factor in the line strike probability chart is not a standalone probability of tree failure. Rather, the risk factor is used to compare two or more construction or maintenance options for a specific area.

The line strike probability chart (Figure 8 ) shows that at a $0 \mathrm{~m}$ clear width, the risk factor is 1 . The risk factor reaches 0 when the clear width is so great that no falling tree can strike the line. In this example, the risk factor reaches 0 at an $18 \mathrm{~m}$ clear width. A point of particular interest evident in the line strike probability chart (Figure 8) is that there is a point of diminishing return in line security for the dollar invested in increasing clear width. In this example, that point is at a clear width of 6 to $7 \mathrm{~m}$. At a clear width of 6 to $7 \mathrm{~m}$, the risk factor passes through the value of 0.2 . Stating it in another way, assuming the variables in this example, a 6 to $7 \mathrm{~m}$ clear width reduces the risk of trees striking the line by $80 \%$. The percentage of trees removed to attain the 0.2 risk factor is $39 \%(7 \mathrm{~m} / 18 \mathrm{~m} \times 100)$.

The point at which clear width provides a diminishing return in line security can provide guidance for the extent of easement required on new lines where an optimal balance between cost and reliability is desired.

The data produced by the line strike probability chart can be used in a number of ways. To illustrate, three examples are provided. 


\section{Example 1}

A section of distribution line running through a forested area is identified as problematic. Under windy conditions, trees fail and take the line out. The hazard tree removal program has had limited success. Perhaps widening the right of way is the solution? But it is difficult to justify making a major investment without a means of forecasting the benefit - the impact on reliability.

To produce a line strike probability chart, certain field data are required. Assume the following conditions:

- line height: $9.1 \mathrm{~m}(30 \mathrm{ft})$

- tree height: $27.3 \mathrm{~m}(90 \mathrm{ft})$

- trees/ha: 298 (120 trees/ac)

- current clear width: $3 \mathrm{~m}$ (10 ft)

What would be the benefit of increasing the clear width to $6.1 \mathrm{~m}(20 \mathrm{ft})$ ?

Reading from the line strike probability chart (Figure 9), at a $3 \mathrm{~m}(10 \mathrm{ft})$ clear width, the risk factor is about 0.68 while at a $6.1 \mathrm{~m}(20 \mathrm{ft})$ clear width the risk factor is about 0.42 . That information can then be put into a simple spreadsheet (Figure 10), which shows increasing the clear width another $3 \mathrm{~m}$ would result in a 37\% improvement in line security.

Adding unit costs to the spreadsheet facilitates a quick assessment of the cost versus the benefit in increased line security. In this way, the cost for improvement in reliability gained through right-of-way widening can be compared to alternatives such as increasing line height, differing construction, undergrounding, or using protective devices.

\section{Example 2}

Your utility company plans to build another transmission line. Due to siting difficulties, the most expedient approvals are likely if the line is added to an existing right-of-way. Applying to increase the current easement may also result in delays, so the company favors using the existing right-of-way. Before finalizing this decision, management would like an assessment of the impact this action will have on line security.

Assume the following conditions:

- seventy percent of the line runs through forest; the clear width will be reduced to $9.1 \mathrm{~m}$ (30 ft)

- line height: $18.2 \mathrm{~m}(60 \mathrm{ft})$

- tree height: $27.3 \mathrm{~m}(90 \mathrm{ft})$

- trees/ha: 298 (120 trees/ac)

- current clear width: $19.7 \mathrm{~m}$ (65 ft)

A line strike probability chart is produced (Figure 9). From that chart we see that at a $19.7 \mathrm{~m}(65 \mathrm{ft})$ clear width,

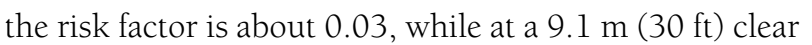
width, the risk factor is about 0.26 . Entering this information into a spreadsheet (Figure 11) shows the impact of

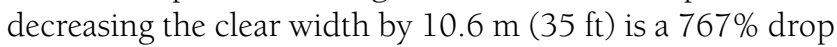

in line security. In other words, one should expect about eight times the current number of tree-related outages.

\section{Example 3}

A $48 \mathrm{~km}$ (30 mi) segment of a $240 \mathrm{~km}$ (150 mi) $25 \mathrm{kV}$ circuit is being rebuilt. A new $69 \mathrm{kV}$ line is being constructed and for the portion of the overlap the $25 \mathrm{kV}$ circuit will be understrung on the taller $69 \mathrm{kV}$ structures. There have been a significant number of tree problems on the $25 \mathrm{kV}$ line. The records indicate that over the length of the line there were seven tree-caused outages in the past year. Management has indicated that this level of reliability is unacceptable for a 69 $\mathrm{kV}$ line. They have asked what would be required to reduce the tree incidents to no more than one in 3 years. Engineering has told you that they plan to build the $69 \mathrm{kV}$ line on 3 $\mathrm{m}(10 \mathrm{ft})$ cross arms, and the average line height would be $12.2 \mathrm{~m}(40 \mathrm{ft})$.

Assume you find the following field conditions:

- The current $25 \mathrm{kV}$ line is built on $2.4 \mathrm{~m}$ ( $8 \mathrm{ft}$ ) cross arms, and the average conductor height is $8.5 \mathrm{~m}(28 \mathrm{ft})$. Sixty percent of the line runs adjacent to a forest edge. The poles are situated at the edge of a $20 \mathrm{~m}(66 \mathrm{ft}) \mathrm{road}$ allowance.

- current $25 \mathrm{kV}$ conditions:

- line height: $8.5 \mathrm{~m}(28 \mathrm{ft})$

- tree height: $25.8 \mathrm{~m}(85 \mathrm{ft})$

- trees/ha: 620 (250 trees/ac)

- current clear width: $4.5 \mathrm{~m}$ (15ft)

- $69 \mathrm{kV}$ conditions as proposed:

- line height: $12.2 \mathrm{~m}$ (40 ft)

- current clear width: $4.2 \mathrm{~m}$ (14ft)

Two line strike probability charts need to be produced: one

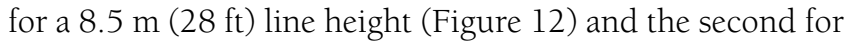

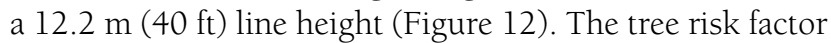
for the current situation ( $28 \mathrm{ft}$ height and $15 \mathrm{ft}$ clear width) is 0.50 . The tree risk factor for the $69 \mathrm{kV}$ line on the same ROW (40 ft height and $14 \mathrm{ft}$ clear width) would be 0.50 . Hence, the number of tree-conductor incidents on the 69 $\mathrm{kV}$ line would be $0.50 / 0.50$ of those experienced on the current $25 \mathrm{kV}$ line.

Then you need to determine the amount of improvement required in line security to achieve the management objective of no more than one tree-caused outage over 3 years. This could be expressed as 0.33 outages per year.

You calculate the required increase in line security to be $76 \%$ :

$$
\begin{gathered}
\left(1-\left(.33 \text { outages } \mathrm{yr}^{-1} /\left(.50 / .50 \times 7 \text { outages } \mathrm{yr}^{-1} / 150 \mathrm{mi} \times\right.\right.\right. \\
30 \mathrm{mi})) \times 100)
\end{gathered}
$$

Using a spreadsheet (Figure 13), you enter the tree and line data and the starting tree risk factor of 0.50 (derived from the chart Figure 12). Then by iterations of decreasing 
the new risk factor value, you determine the risk factor value that brings the line security improvement as close as possible to $76 \%$. That value is 0.12 . Returning to Figure 12 , we see that a risk factor of 0.12 occurs at a $10.6 \mathrm{~m}(35 \mathrm{ft}$ ) clear width. The distance from the tree line to the center line needs to be $35 \mathrm{ft}+10 \mathrm{ft} / 2$ (cross arm), or $40 \mathrm{ft}$. Given that the line runs along a road allowance, the road side portion has more than adequate clearance.

You advise management that you can meet the objective of no more than one outage in 3 years provided the easement is increased by $20 \mathrm{ft}$ on the off-road side and that you receive increased funding of $\$ 91,638\left(\$ 5,091 \mathrm{mi}^{-1}\right.$ x $30 \mathrm{mi} \times$ 0.6 tree covered) to widen the right-of-way.

These three examples illustrate the utility of forecasting the impact of actions on line security. While risk is quantified in percentage terms, where the history of tree incidents is known, a simple calculation can convert the data to the number of tree incidents to expect in the future (as in Example 3). In doing so, it should be recognized that it is an estimate that assumes the same tree and weather conditions from one year to the next.

The approach used in arriving at the risk factor assumes all trees are susceptible to failure and as such, all trees capable of striking the line represent a liability. While this represents a worst-case scenario, it recognizes that we cannot predict which healthy trees in a stand will next succumb to the stresses of competition. Thus, while varying tree mortality rates influence the scope and intensity of the hazard tree program that should be applied to the residual trees, mortality rates do not alter the risk factor.

One risk factor rating, taken in isolation, provides no information about the number of tree-caused outages experienced on or projected for a line segment. It is only when the risk factor is used on a comparative basis that it becomes a tool that informs the process of selecting between maintenance or construction options. The three examples illustrate that the changes in risk factor arose from changes in the variables of line height and/or clear width. Tree species failure and decay characteristics that either contribute to or decrease the likelihood of line outages are the same for each possible option. These tree species failure and decay characteristics are also reflected in the tree-related outage experience. Hence, the risk factor can be used to derive a percentage change in reliability without the need to identify the specific tree failure modes.

\section{IMPORTANCE OF TARGET CLEARANCE: A CASE STUDY}

To this point, tree risk quantification has been examined in the context of applying it to new construction and problematic line segments. However, in a sense, utilities have set their tree risk exposure on a systemwide basis by the clearance standards adopted.
The factors affecting tree-related outages are (Guggenmoos 1996)

- tree density (number of trees per mile of line)

- clear distance (horizontal distance, measured on the ground, from tree edge to nearest conductor)

- tree species (based on specific characteristics such as mature height, propensity to shed branches, break, bend or uproot)

- soil characteristics

- disease and insect pests

- weather events such as wind, ice and wet snow

- landscape characteristics such as slope

Examining these factors, there is only one utilities can control: the clear distance (Guggenmoos 1996). The maintenance cycle is not included in this list since it would be determined by tree species characteristics, climatic factors, and clear distance. That is, the maintenance cycle and clear distance are totally interdependent. If the clear distance is set, then the maintenance cycle is determined by the time it takes for growth to span the clear distance or reach the limit of approach. If the maintenance cycle is set, then the clear distance must be adjusted to reflect the amount of growth over the cycle.

When a line clearance program is under review, both the clear distance and maintenance cycle may be reviewed and adjusted, as was the case when TransAlta Utilities' program came under review in 1985. In spite of line clearance budget increases averaging 32\% between 1980 and 1985, treerelated outages were expanding exponentially (Guggenmoos 1995) (Figure 14). At the time of the review, pruning clearances averaged $3 \mathrm{~m}(10 \mathrm{ft})$. To increase the cycle length, the target pruning clearance was increased to $4.5 \mathrm{~m}$ (15 ft). It was decided that trees overhanging lines would not be acceptable. All overhangs would be removed. Side clearance, which was initially $6 \mathrm{~m}$ back in the 1950s when rural lines were built, had experienced some in-growth to average $5 \mathrm{~m}$. Just before the new line-clearance program based on a tree inventory and local growth rates was launched in 1986, a decision was made to measure the target $6 \mathrm{~m}$ side clearance at line height to the nearest tree part, rather than along the ground (clear width). The result of this decision was that the clear width, as measured to the trunks of adjacent trees, was increased on average by $4 \mathrm{~m}$. This decision had a profound impact on treerelated outages.

Tree-related outages increased from 1985 through 1987 but then began a steady decrease. In fact, by 1991, treerelated outages dropped 80\% from the 1987 levels (Figure 14). A $70 \%$ reduction can be explained by the increased clear width (Figure 15) using averages for tree height, tree density, and line height. The remainder of the reliability gain is attributed to the removal of overhangs (only $0.3 \%$ of total trims) and appropriate pruning cycles. 
TransAlta's experience illustrates the clear distance standard selected is a key determinant of the number of tree-related outages.

That $85 \%$ of the tree-caused outages arise from off-ROW trees is problematic because it brings the utility into conflict with property rights. While that would appear to rule out any increases in clear width without legally increasing the easement, it need not be so. In fact, TransAlta distribution lines had no easements except on crown land, which comprised less than $15 \%$ of the line miles. Increasing the clear width could only be achieved through the willing cooperation of the landowners.

\section{CONCLUSION}

Considering tree and typical line heights, common maintained right-of-way widths eliminate tall-growing and potentially conflicting trees from only a fraction of the area along power lines. For both transmission and distribution lines, the major source of tree conflicts is from off-ROW trees.

The clear widths used by North American utilities are fairly standard and not greatly variable. However, the exposure of power lines to possible tree-conductor conflicts is highly variable due to variable amounts of forest cover. In many states and provinces of North America, forests cover more than $50 \%$ of the land base (Smith and Sheffield 2000; U.S. Forest Service 2000,

Forestinformation.com, no date).

The available information suggests that for North American utilities having both urban and rural lines, tree failure will be responsible for about $85 \%$ of all tree-caused outages, regardless of the number of trees per mile of line. While pruning trees on the right-of-way is essential for public safety, to make significant improvements in electric system reliability, the risks arising from adjacent, off-ROW trees must be identified and addressed. Typically these risks are addressed through a hazard tree identification and removal program. There has been an industry focus on improving the science of hazard tree assessments and increasing staff and contractor competencies in the identification of these hazards. However, a gap in utility arboriculture literature regarding natural tree mortality rates and their implications for achieving reliability improvements suggests an area deserving of consideration.

Common annual tree stand mortality rates ranging from $0.5 \%$ to $3 \%$ reveal that the rate of hazard tree formation or additions is substantially higher than removal rates through hazard tree programs. Given that natural tree mortality adds 21 to 150 trees $\mathrm{mi}^{-1} \mathrm{yr}^{-1}$ per treed ROW side, it is probable that most hazard tree programs will do little to appreciably improve reliability for more than a few years. When a hazard tree program does substantially improve reliability, over time the majority of the gains will be eroded by tree mortality.
Tree-conductor conflict risks are not limited to dead and decadent trees. High winds, ice, wet snow, and lightning can cause healthy, structurally sound trees to fail. Hence, all trees capable of interfering with power lines constitute a risk to the safe, reliable transmission of electricity.

Tree height, line height, tree density, and clear width are variables that can be altered to improve line security. A mathematical derivation of tree risk using these variables was used to produce line strike probability charts. The line strike probability chart reveals there is a point of diminishing return in line security as clear width increases. In most cases, making a power line tree-free would not be financially prudent. The nature of the line strike probability curve presents a visual that both clarifies and simplifies the understanding of the risk of trees in proximity of power lines. As such, it may serve as a useful communication tool among utilities and stakeholders such as federal and state foresters, community groups, and regulators.

The variables used in the quantification of the tree risk facilitate the derivation of the cost of specified reliability improvements. The cost of benefits can be readily compared to alternatives, such as increasing conductor height, installing tree wire, or undergrounding. Being able to calculate the cost of benefits opens an avenue to balancing the liability associated with incurring an outage with an acceptable degree of risk.

An examination of North American forest stand data shows a common trait, that of decreasing tree density over time. It is recognized, however, that for trees, death is a process-not an event at one specific point in time. Dead or decadent trees retain a certain structural strength and fail when conditions arise that place them under unbearable stress. The occurrences of such conditions of stress are weather related. Thus, while this quantitative approach to managing tree-conductor conflicts offers benefits under relatively normal weather conditions, the larger opportunity lies in the avoidance of wind- and storm-related tree outages.

The use of line strike probability charts could be particularly advantageous when there is a major pest infestation that significantly increases tree mortality. The usual maintenance approach would be to make numerous passes identifying and removing hazard trees. It may prove more economical to drastically reduce the number of trees capable of striking the line by widening the right-of-way to the point where clear width provides a diminishing return in line security. Under these circumstances, this approach may appeal to forestry staff because the tree numbers may be high enough to justify salvage rather than simply dropping the trees into the forest. In widening, the residual area requiring hazard tree identification is reduced, correspondingly avoiding costs. Further, by concentrating a major tree volume to one maintenance event, the feasibility of more economical, mechanized removal methods is enhanced. 
The derivation of tree risk that has been outlined views all trees capable of interfering with power lines as a risk. While a quantitative tree risk factor can be comparatively applied, it does not provide a measure of risk under variable weather conditions. A logical extension of this approach would include a study of tree failure rates, by species, under various wind intensities; the frequency of destructive ice or snow and wind storms; and the direction of severe storms. These factors would serve to both to reduce the tree risk rating and move toward predictive measures of the probability of experiencing tree-caused outages and the severity of system damage.

The mathematical quantification of tree risk applied to priority areas as identified by outage statistics provides an opportunity to manage so-called unpreventable tree-caused outages for real and lasting gains in reliability. Increasing conductor height and the clear width will improve reliability. However, unless a line is completely tree-free, a hazard tree program remains an integral part of the maintenance process. The number and condition of residual trees will impact line security. The success of the hazard tree program will be improved because it need only be applied to a reduced tree population or residual risk. Most important, a quantitative approach to managing the risk of tree-conductor conflicts provides a means to progressively improve electric system reliability.

\section{LITERATURE CITED}

Bush, R. 2002. In the reliability hot seat. Transmission \& Distribution World Feb. 1.

Business Wires Features. 2001. Home Grown? U.S. Consumers Show Increasing Interest in Generating Their Own Electricity. Jan. 29.

California Public Utilities Commission. 2000. Rulemaking for Electric Distribution Facility Standard Setting. May 4, 2000. Attachment 1, Additional Provisions to G.O. 166.

Campbell, S., and L. Liegel (Tech Coords.). 1996. Mortality trends. Chapter 1, in Disturbance and Forest Health in Oregon and Washington. Gen. Tech. Rep. PNW-GTR-381. U.S. Department of Agriculture, Forest Service, Pacific Northwest Research Station, Portland, OR; Oregon Department of Forestry; and Washington Department of Natural Resources.

Carris, P.S. 2000. Preventing the non-preventable treerelated outage. UAA Q. 9(1).

Crookston, N..L. 1997. Suppose: An Interface to the Forest Vegetation Simulator. In Teck, R., M. Moeur, and J. Adams (Eds.) Proceeding: Forest Vegetation Simulator Conference. 3-7 Feb. 1997. Fort Collins, CO. Gen. Tech. Rpt. INT-GTR-373. U.S. Department of Agriculture, Forest Service, Intermountain Research Station, Ogden, UT.

Curtis, R.O., G.W. Clendenen, and J.A. Henderson, 2000. True Fir-Hemlock Spacing Trials: Design and First
Results. Gen. Tech. Rpt. PNW-GTR-492. U.S. Department of Agriculture, Forest Service, Pacific Northwest Research Station, Portland, OR.

Desbiens, R. 2001. Bulking up for the next storm. Transmission \& Distribution World Apr 1.

Electric Perspectives. 2001. News \& trends: Jobs well done I: Emergency response. Mar/Apr.

EnergyOnline Daily News. 1996a. Energy Department Calls Last Month's Western Outage 'Preventable'. www.energyonline.com/news/articles/Archive/ outage.asp.

- 1996b. California PUC on Big Outage: Let Us Know When a Line's Down. www.energyonline.com/news/ articles/Archive/outage2.asp.

—. 1996c. PG\&E's Big Bill from the Arborists. www.energyonline.com/news/articles/Archive/ pg_e_arb.asp.

— 1997a. PG\&E Faces Record Fines for 1994 Sierra Wildfire. www.energyonline.com/news/articles/Archive/ 0623ca.asp.

_ 1997b. Mother Lode Fire Costs PG\&E \$2 Million. www.energyonline.com/news/articles/Archive/0721ca.asp. 1997c. Wildfires: It's SoCal Ed's Turn on the Hot Seat. www.energyonline.com/news/articles/Archive/ 1002cal.asp.

- 1998a. At Least 6 Dead, 3 Million Without Power As Killer Storm Savages Eastern Provinces. www.energyonline.com/news/articles/Archive/a09can.asp. 1998b. CPUC Orders Probe of PG\&E Tree-

Trimming Practices. www.energyonline.com/news/ articles/Archive/i04ca.asp.

1998c. SDG\&E Damned If It Does ... or Doesn't. www.energyonline.com/news/articles/Archive/j02safe.asp.

EPRI. 1995. The Right Tree for the Right-of-Way. Technical Brief, TB-105029. Abstract at www.epri.com/ OrderableitemDesc.asp?...0\&marketnid $=1$ \&oitype $=$ 5 \&searchdate $=4 / 4 / 1995$

Finch, K.E., and C. Allen. 2001. Understanding Tree-Caused Outages. EEI Natural Resource Conference. Apr. 2001. Palm Springs, CA.

Forestinformation.com. Forest Statistics. www.forestinformation.com/index.asp.

Goodfellow, J.W. 2000. Understanding the Way Trees Cause Outages. ECI and Allegheny Power. Slide presentation (34 slides).

Grayson, L. 2001. Legislative and regulatory update: State regulatory issues. UAA Q. 10(1).

Guggenmoos, S. 1995. New program controls tree management. Electric Light and Power, 73(2):15-18.

- 1996. Outage statistics as a basis for determining line clearance program status. UAA Q. 5(1).

- 2000. Introducing A New VM Tool \& Service, Optimal Clear Width Calculator. clubweb.interbaun.com/ ecosync/OCWC.htm. 
Hadden, E. 2001. Weather lessons. Transmission \& Distribution World Apr. 1.

Harmon, M.E. 1999. Andrews Experimental Forest. Regional Studies in the Pacific Northwest: H.J. Andrews Experimental Forest Long-Term Ecological Research (LTER) Program. www.fsl.orst.edu/lter/research/ regionl.htm.

Johnson, R. R. 1990. East Cascades Prognosis Geographic Variant of the Forest Vegetation Simulator. WO-TM Service Center, U.S. Department of Agriculture, Forest Service.

Johnstone, R.A. 2001. Changing Expectations in Utility Arboriculure. EEI Natural Resource Conference. Apr. 2001, Palm Springs, CA.

Johnstone, W.D. 1976. Variable-density yield tables for natural stands of lodgepole pine in

Alberta. Can. For. Serv., Dept. Fish. Envir., For. Tech. Rep. 20, p. 110.

Keener, R.N., Jr. No date. The Estimated Impact of Weather on Daily Electric Utility Operations. Duke Power Company, Charlotte, NC. www.esig.ucar.edu/socasp/ weatherl/keener.html.

Kjellstrand, L. 1998. PUC Penalizes EGS for Inadequate Service, Customers to Get Refund When Order is Final. Public Utility Commission of Texas, News Releases. www.puc.state.tx.us/nrelease/1998/011498a.cfm.

Lewis, S.M. 2001. Utilities Cannot Afford to Become "Sometimes Power \& Light." Transmission \& Distribution World Apr. 1.

Lilly, B.. 2000. The Southeast Variant of the Forest Vegetation Simulator. Forest Management Service Center, Fort Collins, CO.

Louisiana Public Service Commission. 1998. General Order of April 30, 1998, Ensuring Reliable Electric Service. Docket No. U-22389.

Megawatt Daily. 1999. Michigan Tells Detroit Edison to Improve Reliability. Dec. 1.

Michigan Public Service Commission, Electric Division, 2000. Proposed Michigan Electric Distribution System Performance Standards. Case No. U-12270. May 1.

Olsen, M. 2001. Life on the lines. Sacramento News \& Review Apr 19.

Oregon Public Utility Commission. 2001. Five-Year Electric Service Reliability Study 1996-2000. OAR 860-0230080(9).

Owens, D.K. 2001. Strengthening the Critical Link. EEI Electric Perspectives July/Aug.

Partners in Protection. 1999. FireSmart: Protecting Your Community from Wildfire. Chapter 1, in Vicars, M. (Ed.). Partners in Protection, Edmonton, AB.
Plonski, W.L. 1981. Normal Yield Tables (Metric) for Major Forest Species in Ontario. Ontario Ministry Natural Resources, For. Res. Group, Toronto, ON.

Poole, D., and K. Clements. 2000. IP wants greater treetrimming freedom. The News-Gazette, newsgazette.com/ ngsearch/story.cfm?number $=8473$.

PRNewswire. 1999. Detroit Edison Honored for Electric Service Reliability Programs. Oct. 25.

Rees, W.T., Jr., T.C. Birx, D.L. Neal, C.J. Summerson, F.L. Tiburzi, Jr., and J.A. Thurber. 1994. Priority Trimming to Improve Reliability. ISA conference presentation, Halifax, NS.

Rights-of-Way Online. 1999. Regulators Demand Reliability. BASF. www.rightsofway.com/rightsofway/article.asp?at= DEMAND\&nl=w1999.

Rogers, B.I. 2001. Puget Sound Energy Tree Watch Program. EEI Natural Resource Conference, Apr. 2001, Palm Springs, CA.

St. Petersburg Times. 1999. Florida Electric Utilities Refocus on Reliability, Customer Service. May 19.

Simpson, P., and R. Van Bossuyt. Tree-Caused Electric Outages. J. Arboric. 22(3).

Smith, W.B., and R.M. Sheffield. 2000. A Brief Overview of the Forest Resources of the United States, 1997. USDA Forest Service, Washington, DC.

Watson, R.T., M.C. Zinyowera, and R.H. Moss (Eds.). 1998. The Regional Impacts of Climate Change-An Assessment of Vulnerability (1998). A special report of the Intergovernmental Panel on Climate Change, Working Group II. Cambridge University Press, UK.

Transmission \& Distribution World. 2002. Vegetation Management. industryclick.com/magazinearticle.asp? magazineid $=108 \&$ releaseid $=10001$ \&magazinearticleid $=$ $144108 \&$ siteid $=14$.

Tomich, J. 2001. Arkansas Ice Storm Cruel to Poorly Maintained Electric Lines. Arkansas Democrat-Gazette Jan. 9.

U.S. Forest Service. 2000. Forest Inventory and Analysis. Resource Planning Act Assessments. 1997 RPA: The United States Forest Resource Current Situation, Final 1997 RPA Tables, fia.fs.fed.us/rpa.htm

- 2001. U.S. Forest Facts and Historical Trends. U.S. Dept. of Agriculture, Forest Service, FS-696, fia.fs.fed.us.

President, Ecological Solutions, Inc. 10 Milburn Place

Sherwood Park, AB, T8A OT8

Canada 


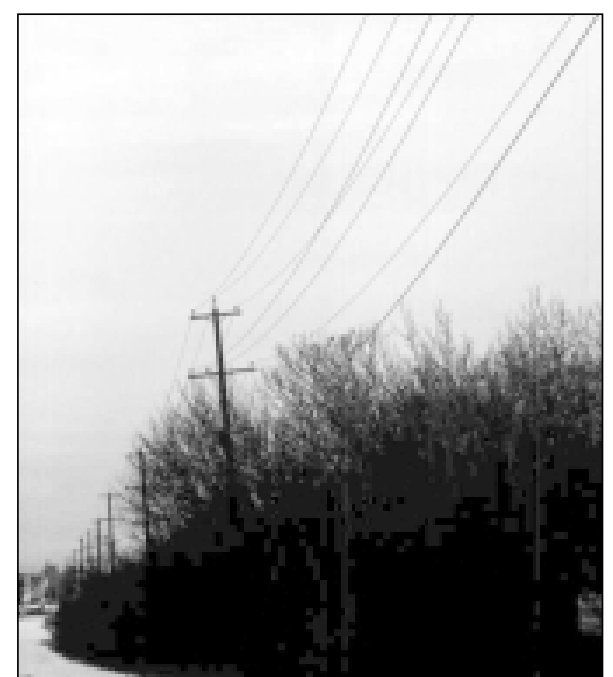

Figure 1. New growth has been "burnt off" from occasional line contact (center of photo).

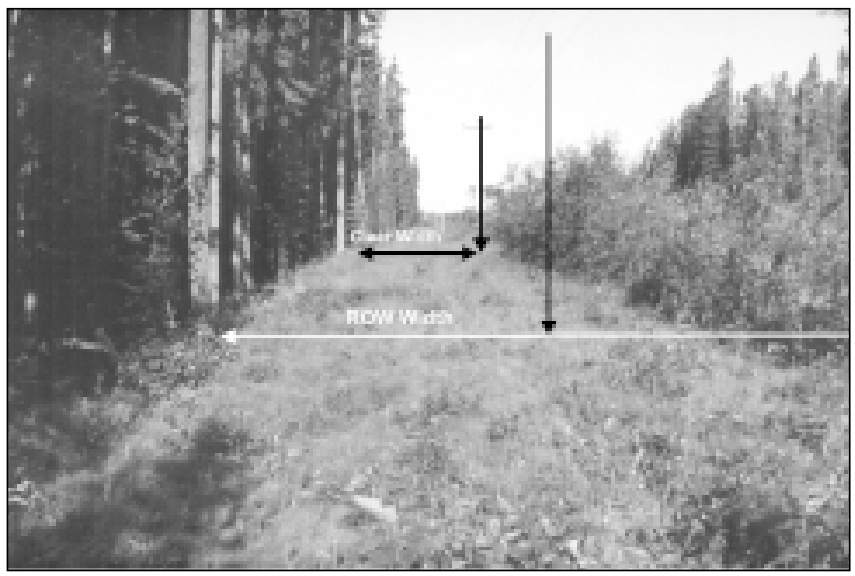

Figure 2. Clear width: The distance measured on the ground from the trunks at the tree line to the nearest conductor.

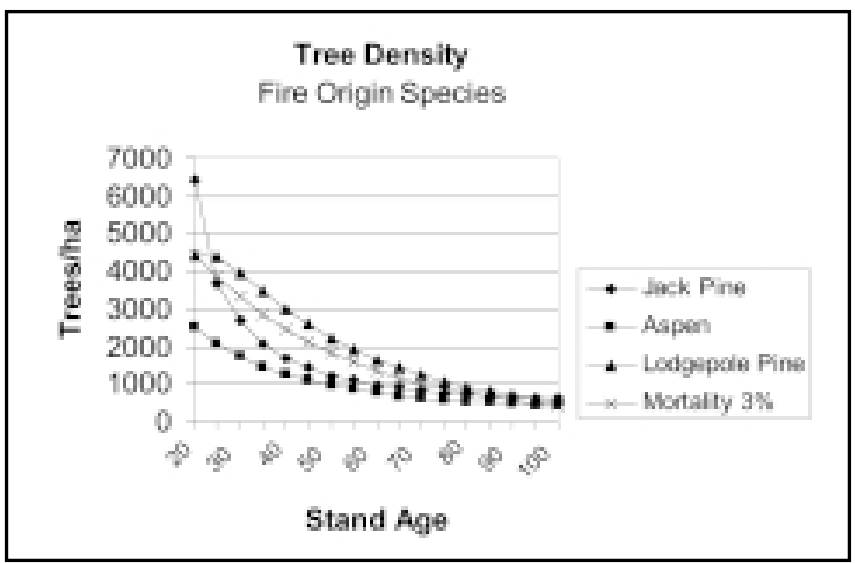

Figure 3. Natural tree mortality numbers in the thousands of trees/ha. Most of the dying trees pose a potential risk to power lines (Johnstone 1978 and Plonski 1981).

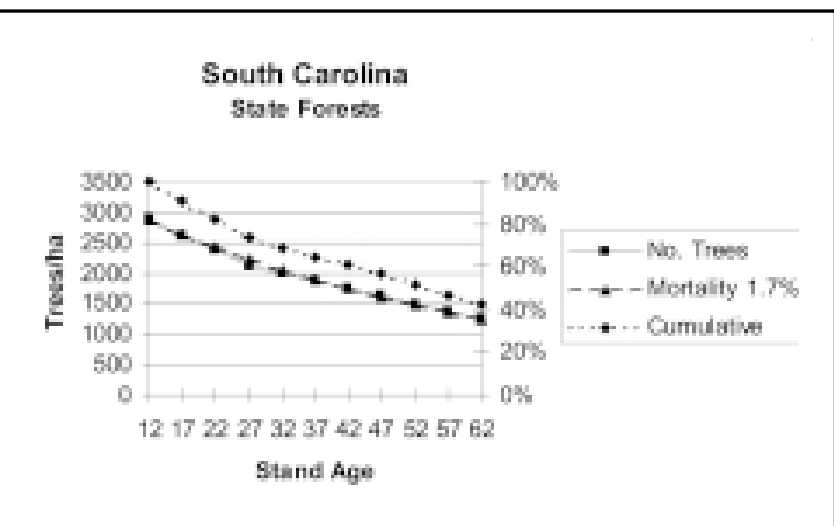

Figure 4. Sixty percent of the trees in the stand die over 50 years. More than $40 \%$ are tall enough to disrupt distribution service.

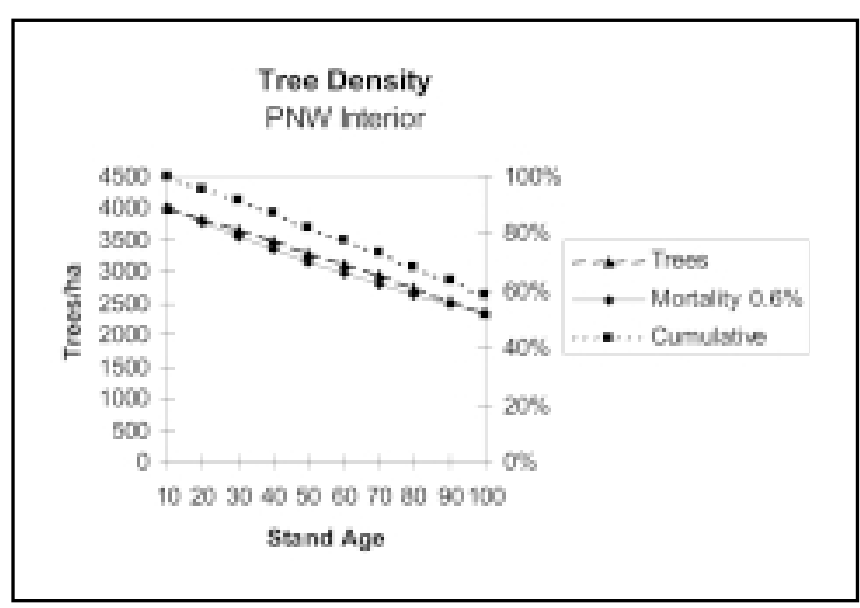

Figure 5. Mortality is $40 \%$ over 90 years, averaging 18 trees/ha annually.

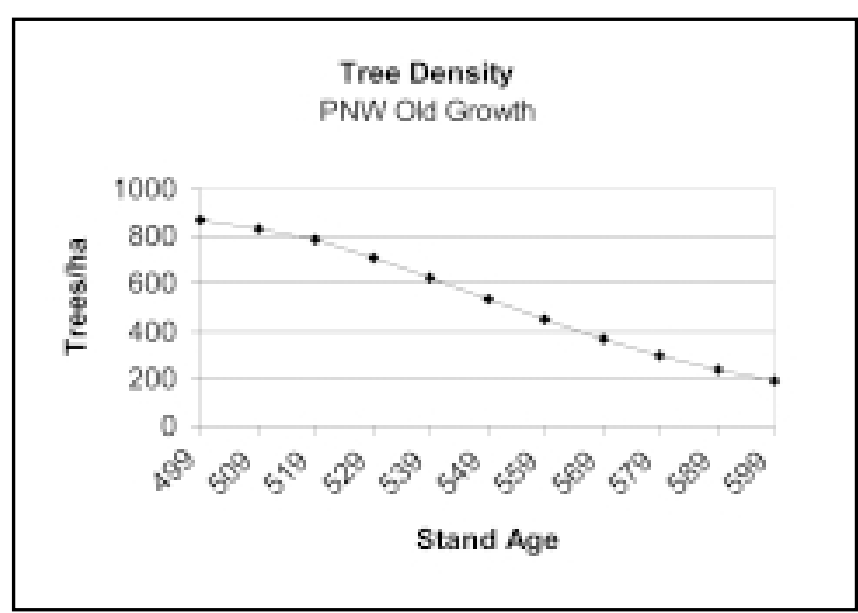

Figure 6. Very old tree stands continue the pattern of decreasing tree stand density over time. 


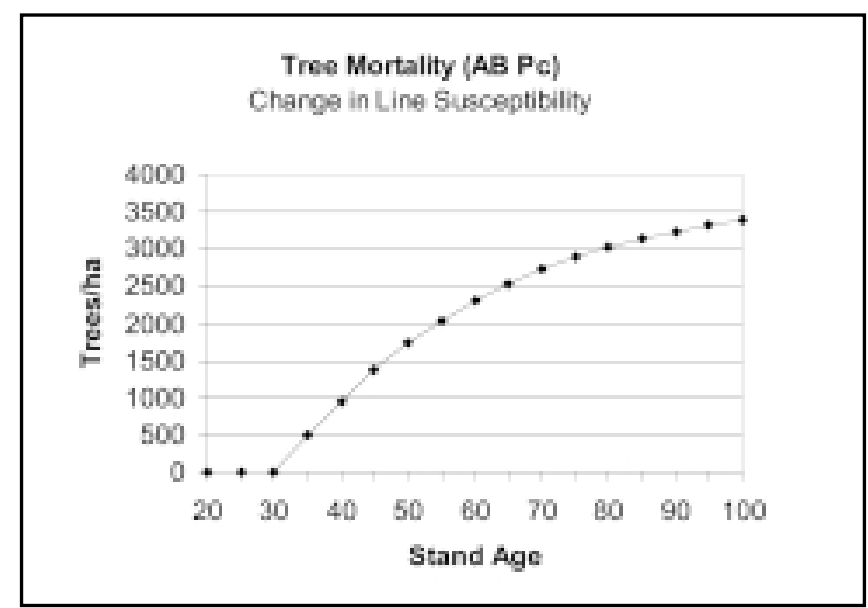

Figure 7. The risk to a power line due to tree mortality builds up rapidly. From stand age 30 to 40 years, hazard tree additions are about 100 trees/ha per year (adapted from Johnstone 1976 and Guggenmoos 1996).

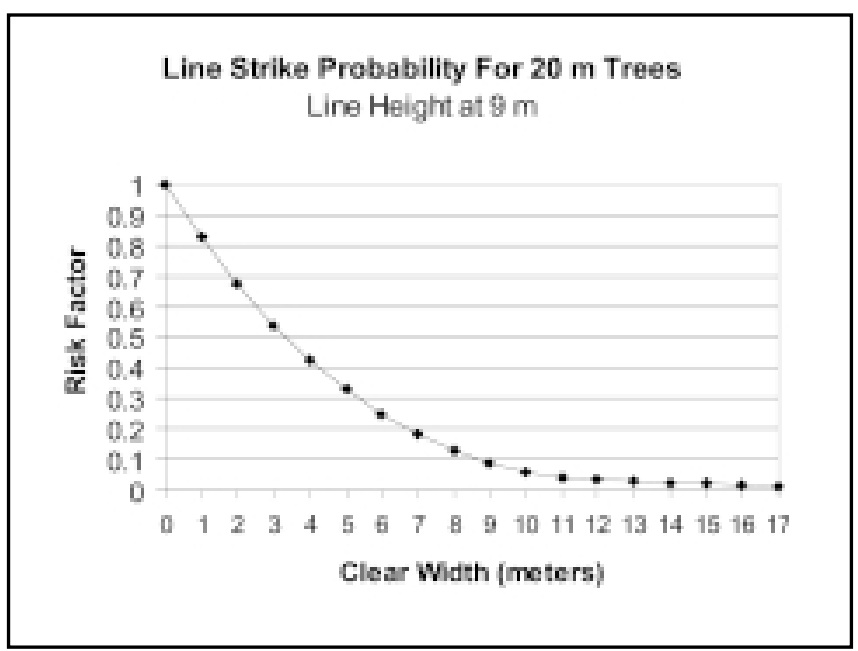

Figure 8 . Where clear width is 0 , the risk is considered to be $100 \%$, or 1 . When clear width is so large that trees cannot contact the line on failure (about $18 \mathrm{~m}$ in this example), the risk is 0 .

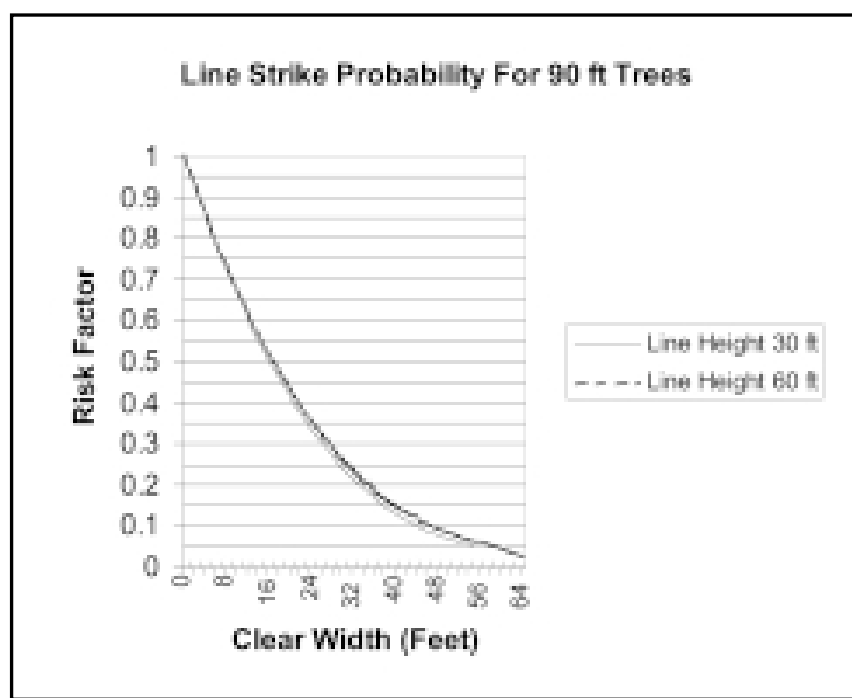

Figure 9. Line strike probability chart produced byt he optimal clear width calculator for the tree height, line height, and tree density variables in Examples 1 and 2.

\begin{tabular}{|c|c|c|c|c|c|}
\hline \multicolumn{3}{|c|}{ Cost: Benefit Analysis } & & & \multirow[b]{2}{*}{$\begin{array}{l}\text { Line Security } \\
\text { Improvement }\end{array}$} \\
\hline $\begin{array}{l}\text { Line Segment } \\
\text { Specific: }\end{array}$ & & Acjmi & Treesimi & & \\
\hline Line theight & 30 & & & & \\
\hline Tree Height & 90 & & & & \\
\hline Treessace & 120 & & & & \\
\hline Current Clear Width & 10 & & & & \\
\hline Current Rush Factor & 0.67 & & & & \\
\hline Increase Width & 10 & 1.21 & 145 & & \\
\hline Never forsh Factor & 0.42 & & & & $37 \%$ \\
\hline Remeval Cesalres * & $\$ 8$ & & & $\$ 1,164$ & \\
\hline Remeval Cosblree " & 960 & & & $\$ 8.727$ & \\
\hline - Ubing faler burcher & & & & & \\
\hline * Crarnim retovib & & & & & \\
\hline
\end{tabular}

Figure 10. A spreadsheet permits a quick derivation of the line-security implications for a proposed change in clear width or line height. Addition of tree removal costs reveals the cost versus the line-security benefit.

\begin{tabular}{|c|c|c|c|c|c|}
\hline \multicolumn{6}{|c|}{ Cost: Benefit Analysis } \\
\hline $\begin{array}{l}\text { Line Segment } \\
\text { Specific: }\end{array}$ & & Acjmi & Trues/mi & Costimi & $\begin{array}{l}\text { Line Security } \\
\text { Improvement }\end{array}$ \\
\hline Line Height & 60 & & & & \\
\hline Tree Height & 90 & & & & \\
\hline Treeslac & 120 & & & & \\
\hline Current Clear Width & 65 & & & & \\
\hline Current Risk Factor & $0.0 \mathrm{~s}$ & & & & \\
\hline Increase Width & 0 & 0.00 & 0 & & \\
\hline New Risk Factor & 0.25 & & & & $-767 \%$ \\
\hline Removal Costutree " & 50 & & & 50 & \\
\hline
\end{tabular}

Figure 11. Tree risk assessment provides a new means of informing the planning and maintenance processes for power lines. 


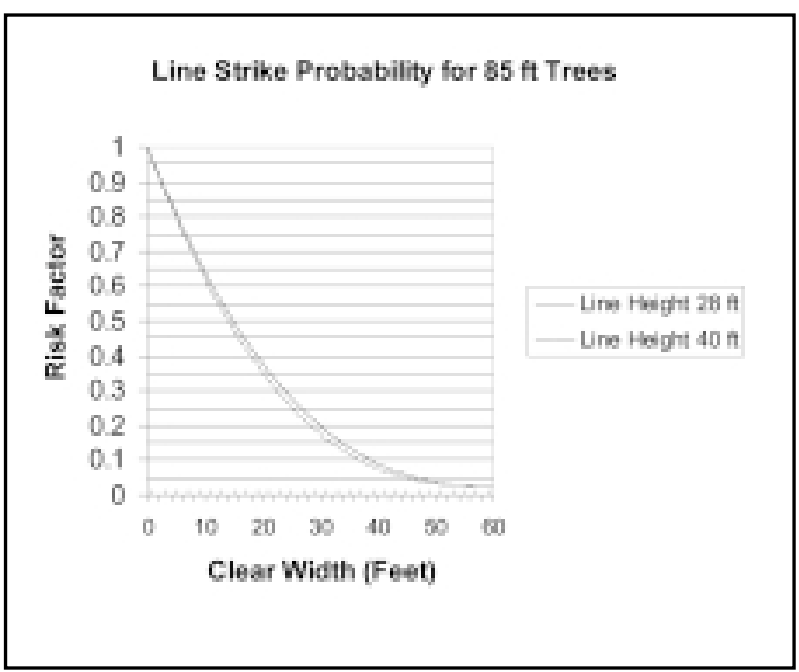

Figure 12. Tree risk assessment is used to compare options for a specific section of power line.

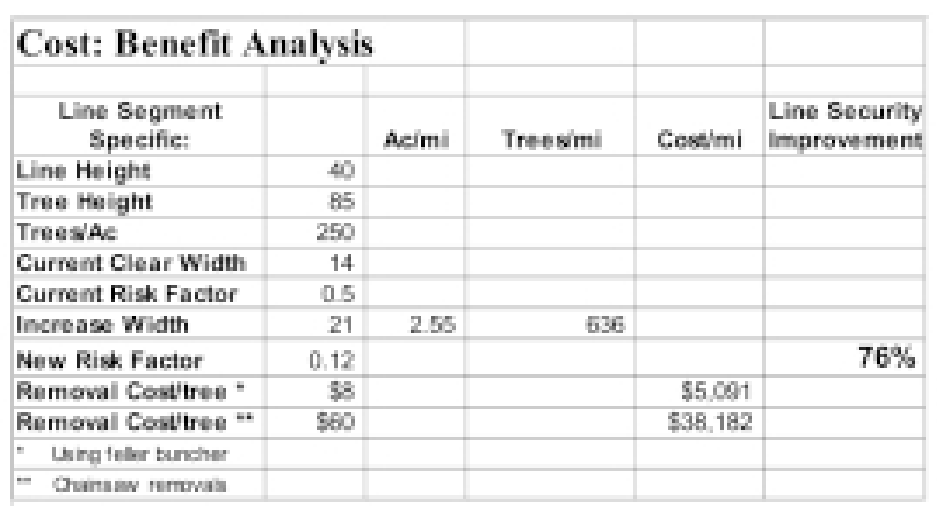

Figure 13. The quanitification of the cost of line-security improvement through reduction in tree exposure via increased clear width may justify investment in alternative construction such as underground lines.

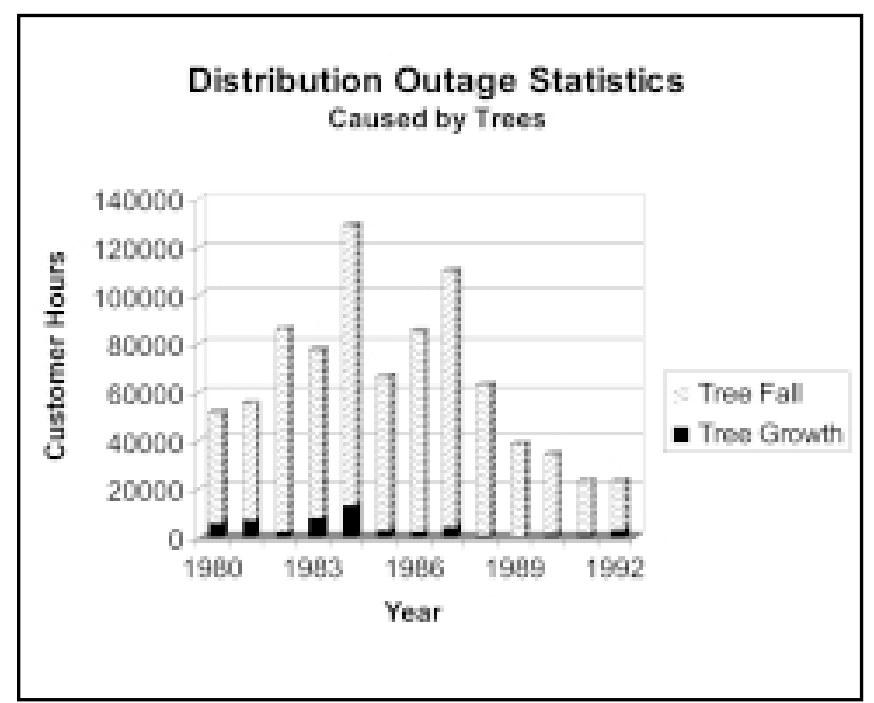

Figure 14. The $80 \%$ tree-caused outage reduction between 1987 and 1991 is attributed to the chosen clearance standards (Guggenmoos 1995).

\begin{tabular}{|l|r|l|l|l|}
\hline \multicolumn{1}{|c|}{$\begin{array}{c}\text { Line Segment } \\
\text { Specific: }\end{array}$} & & Ha/mi Trees/mi Cost/mi & $\begin{array}{l}\text { Line Security } \\
\text { Improvement }\end{array}$ \\
\hline Line Height & 9 & & & \\
\hline Tree Height & 20 & & & \\
\hline Trees/Ha & 1000 & & & \\
\hline Current Clear Width & 5 & & & \\
\hline Current Risk Factor & 0.33 & & & \\
\hline Increase Width & 4 & 0.64 & 640 & \\
\hline New Risk Factor & 0.1 & & & \\
\hline
\end{tabular}

Figure 15. The tree risk assessment process reveals that the chosen clearance standard reduced tree exposure on distribution lines $\mathbf{7 0} \%$. 
Résumé. Des personnes ont rapporté des exemples où les arbres qui poussaient sous des lignes électriques causaient rarement des pannes de courant électrique. La vaste majorité des pannes causées par les arbres l'étaient lors de bris d'arbres, particulièrement si on incluait les pannes survenues lors d'événements climatiques sévères. Généralement, les conflits arbres/conducteurs suite à des bris d'arbres sont classifiés comme imprévisibles parce que les arbres sont localisés hors de l'emprise. Dans un environnement émergent plus compétitif, les compagnies de services vont requérir une moyenne décroissante des pannes dites imprévisibles. Les secteurs primaires des pannes imprévisibles sont les zones où les fils passent à côté ou au travers des milieux forestiers. La mortalité d'arbres expose une ligne électrique dans le temps à un haut degré de risque d'incidents avec un arbre. Le risque pour la ligne est directement relié au nombre d'arbres présents à l'intérieur de la distance de dommages contre la ligne. Les emprises conventionnelles de dégagement laissent un risque résiduel substantiel par rapport aux arbres. Les programmes d'abattage d'arbres à risques ne permettent pas d'obtenir des gains efficaces durables. Un nouveau modèle mathématique, le calcul optimal de largeur d'emprise, est employé pour évaluer le risque des arbres, et ce au travers de largeurs variables de dégagement et de hauteurs des fils. Les degrés de risques dans les chartes de probabilités de dommages aux fils permettent de produire des comparaisons quantitatives d'options de construction et d'entretien. La charte de probabilité de dommages à la ligne indique qu'il y a un point de diminution des bénéfices retrouvés quant à la sécurité de la ligne en fonction de chaque dollar additionnel investi pour élargir la largeur de dégagement de l'emprise.

Zusammenfassung. Andere haben berichtet, daß Vorkommnisse, wo Bäume in Leitungen wachsen, selten zu Stromausfällen führen. Die Mehrzahl von baumbezogenen Stromausfällen resultieren aus Baumversagen, besonders wenn man die Stromausfälle während schlechter Wetterereignisse einbezieht. Im allgemeinen sind die Konflikte, die aus Baumversagen resultieren, als unvorhersehrbar eingestuft, weil die Bäume außerhalb der Oberleitungen lokalisiert sind. In dem zunehmend konkurrenzstarken Umfeld brauchen die Stromversorger ein Gefühl von abnehmenden sogenannten unvorhersehbaren Stromausfällen. Die vorrangigen Bereiche für unvorhersehbare Stromausfälle sind Standorte, wo die Stromversorgung ein Waldgebiet schneidet oder tangiert. Das Baumsterben verursacht ein hohes Risiko für Unfälle entlang der Leitung.. Das Risiko für die Leitung ist direkt verbunden mit der Anzahl der Bäume, in deren Fallbereich die Leitungen liegen. Konventionelle Abstände hinterlassen dennoch ein substanzielles Restrisiko. Die Programme zu Entfernung von Gefahrenbäumen liefern nicht ausreichend eine Entlastung aus der Haftung. Hier wird ein neues mathematisches Modell angewendet, um das Baumrisiko anhand von Parametern wie variabler Abstand und Leitungshöhe zu untersuchen. Die aufgelisteten Risiken in den Stromschlag-Wahrscheinlichkeits-Vermerkblättern erlauben einen quantitativen Vergleich von Konstruktion und Erhaltungsmöglichkeiten. Diese Vermerkblätter zeigen, dass es einen Punkt gibt, die Leitungssicherheit in Relation zum eingesetzten Kapital für zusätzliche Pflege setz..

Resumen. Se han reportado casos donde los árboles que crecen dentro de líneas eléctricas raramente resultan con problemas de fugas de energía. La vasta mayoría de fugas relacionadas con los árboles se dan de fallas durante condiciones climáticas severas. Generalmente, los conflictos por el árbol conductor resultantes de fallas son clasificados como imprevisibles debido a que los árboles están localizados fuera del derecho de vía. Las áreas muchas veces se encuentran donde las líneas corren adyacentes o a través de rodales forestales naturales. La mortalidad de los árboles expone la línea a un riesgo alto de incidentes a través del tiempo. El riesgo está directamente relacionado al número de árboles dentro de la línea. Los aclareos convencionales dejan un riesgo residual de importancia. Los programas de remoción de los árboles peligrosos no son costeables muchas veces y un modelo matemático nuevo, el del Cálculo del Aclareo Óptimo, es usado para evaluar el riesgo del árbol con base en la altura y ancho de la línea. Esto permite comparaciones cuantitativas de construcción y opciones de mantenimiento. La probabilidad de daño indica que hay un punto de retorno por dólares invertidos en aclareo adicional. 